DOI: https://doi.org/10.4796o/2303-7431.24.2020.37

UDK: $321.6 / .7(569.4)$

Pregledni članak

Primljen 2. XII. 2020.

Prihvaćen 13. III. 2021.

GORDANA ILIČIĆ

Sveučilište u Mostaru, Filozofski fakultet

gordana.ilicic@ff.sum.ba

\title{
ALTERNATIVNI OBLICI DEMOKRATSKE DRŽAVE: SLUČAJ IZRAELA
}

\section{Sažetak}

Iako je demokracija u Izraelu održiva i stabilna, ne odgovara ni jednoj od postojećih zapadnih vrsta demokracije. Izrael je tipično podijeljeno društvo čiji su politički sustav i društvena struktura ostatku svijeta često slabo razumljivi. Ovaj rad predstavlja kratku analizu, utemeljenu na teorijskim okvirima i tipološkome smještaju demokracije koja je u uskoj svezi s društvenim rascjepima izraelskoga društva. U radu se ispituje je li se demokracija u Izraelu razvijala tako da olakša upravljanje društvenim podjelama te jesu li se njome ublažili ili ojačali društveni rascjepi.

Ključne riječi: Izrael; etnička demokracija; etnokracija; konsocijacija; podijeljeno društvo

\section{Uvod}

Politika i društvo u Izraelu posebni su iz mnogo razloga: povijesnih, koji su doveli do stvaranja države Izrael, poput preddržavnoga projekta židovske imigracije, Jišuva, i izgradnje društva za vrijeme mandatne uprave u Palestini te holokausta; definicije Izraela kao židovske i demokratske države; nepostojanja priznatih međunarodnih granica kao i 
odnosa većine i manjine između židovskoga i arapskoga stanovništva; dugotrajna ratnog stanja i međusobna prožimanja između vojne i političke elite. ${ }^{1}$ Židovsku povijest i modernu državu Izrael karakterizira neprekidna sinteza partikularističkoga i općega. Mogu se razlučiti dva Izraela: „tradicionalni“, koji je partikularniji, komunitarniji, religiozniji i konzervativniji, te "građanski“, koji je više opći, individualistički, sekularan i liberalniji. Takve dihotomije nikako nisu ograničene samo na Izrael, ali okolnosti njegova nastanka učinile su ih upravo u njemu posebno vidljivima. Istodobno, postoje znakovi približavanja s manje oštrom dihotomijom između „židovskoga“ i „izraelskoga“, gdje se susreću partikularno i opće, unutar kojih Izrael pokazuje da niti može živjeti izolirano niti se može odreći svojih židovskih korijena. ${ }^{2}$

Sustav vlasti u Izraelu svrstava se u oblik parlamentarne demokracije čije se političke strukture sastoje od institucionalnih aranžmana koje se povezuje sa zapadnoeuropskim demokracijama, posebice britanskom parlamentarnom tradicijom te istočnoeuropskim i srednjoeuropskim institucijama i tradicijama, kao i s društveno-političkim obrascima bliskoistočnoga okružja. ${ }^{3}$ Takav splet različitih utjecaja i religijskih, povijesnih i političkih okolnosti čini ovaj sustav vlasti jedinstvenim. Suvremena društvena struktura Izraela plod je različitih naseljeničkih valova, u židovskoj povijesti zvanih alijot. Oni se razlikuju „prema vremenu doseljavanja u Palestinu, zemljama iz kojih su naseljenici potjecali, mjestima na kojima su se nastanjivali, privrednim i društvenim institucijama što su ih gradili u svojim naseljeničkim zajednicama, ideologiji i političkom svjetonazoru što su ih povezivali, te zajedničkim iskustvima stečenima u zemljama u kojima su živjeli, a na kojima su se temeljile zajedničke

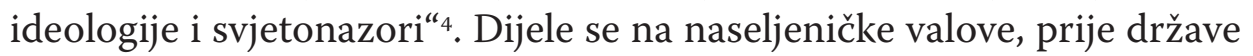

Usp. Helen Chapin Metz (ur.), Israel A Country Study, Library of Congress, Washington, 1990., str. 6. - 79.

2 Usp. Reuven Y. Hazan i dr., „Introduction to Israeli Politics and Societiy“, Reuven Y. HAzan i dr. (ur.) The Oxford Handbook ofI sraeli Politics and Society, Oxford University Press, New York, 2021., str. 13.

3 Usp. Joshua SinaI, „Government and Politics“, H. Chapin Metz (ur.), Israel A Country Study, str. 179.

4 Mirjana Kasapović, Politički sustav i politika Izraela, Politička kultura, Zagreb, 2010., str. 40. 
Izrael, i useljeničke valove, nakon toga. Prvi cionistički naseljenički valovi, do proglašenja Izraela 1948., osnovali su vlastitu društvenu zajedni$\mathrm{cu}$, novi Jišuv, nasuprot staromu Jišuvu, malobrojnoj židovskoj zajednici koja je opstala u Svetoj Zemlji gotovo dvije tisuće godina.

Židovi su živjeli na području Palestine do njihova progonstva, 7o. godine prije Krista. U kasnome 19. stoljeću, kao rezultat židovskoga pitanja u Europi, nastaje cionistički pokret kojemu je glavni cilj bio povratak Židova u domovinu. Do osnutka države 1948. godine u Izrael je stiglo 600.000 useljenika koji su izgradili modernu židovsku zajednicu koja je bila priznata na Zapadu. Nastankom države Izrael i Palestinci nastoje utemeljiti palestinsku državu, što je pokrenulo sukobe nakon kojih je izbio rat koji je rezultirao činjenicom da su Židovi kontrolirali oko 78 \% spornoga teritorija. Od 90o.ooo Palestinaca koji su živjeli na području današnjega Izraela ostalo ih je oko 186.ooo. Iako je Izrael omogućio državljanstvo Arapima, oni su smatrani nelojalnima te su stavljeni pod vojni nadzor, dok je oko polovice njihove zemlje bilo oduzeto. Sredinom 1970-ih Palestinci se počinju organizirati u borbi za ravnopravnost i protiv diskriminacije, pa je trajno ratno stanje još jedno od obilježja Izraela. ${ }^{5}$ Društvena struktura Palestine bila je pod utjecajem višedimenzionalnih naseljeničkih valova. Židovi iz Istočne i Srednje Europe doselili su u Izrael od 1882. do 1948., a nakon neovisnosti u novoosnovanu državu uselio je velik broj bliskoistočnih, sjevernoafričkih i azijskih Židova koji su, uz rastuću arapsku manjinu, bili važno počelo pri oblikovanju suvremene društvene strukture.

Legitimnost društva i identifikacija većinskoga židovskog stanovništva s državom i njezinim institucijama leže na nekoliko važnih temelja: cionizmu, postojanju vanjske prijetnje izraelskoj sigurnosti, judaizmu i demokraciji. Na te temelje utječe arapsko-izraelski sukob i sama priroda izraelskoga, duboko podijeljena društva u kojemu važna arapska manjina sudjeluje u političkome sustavu zemlje, ali ima ambivalentne uloge unutar većinskoga židovskog društva.

Usp. Sammy Sмоoнa, The Model of Ethnic Democracy, European Centre for Minority Issues, Flensburg, 2001., str. 48. - 50. 
Stoga Sammy Smooha svrstava Izrael u povijesno malobrojne etničke demokracije, dok Oren Yiftachel inzistira na označavanju demokracije u Izraelu izrazom etnokracija. Međutim, u oba se slučaja opisuje politička realnost za nežidove u Izraelu na sličan način. ${ }^{6}$ Izrael se često pojavljuje u literaturi i kao jedna od glavnih studija slučaja demokracije u duboko podijeljenu društvu. Zato politički znanstvenici smatraju da je upravo konsocijacijska demokracija, u kojoj se moć dijeli između glavnih skupina, prikladnija za duboko podijeljena društva, poput Izraela, od jednostavne većinske demokracije u kojoj ništa ne razvodnjava vladavinu većine. Izraelska je demokracija u osnovi konsocijacijska, ali samo unutar židovske zajednice, jer se ne suočava sa židovsko-arapskom podjelom, ${ }^{7}$ iako je ta podjela kritična točka demokracije u Izraelu. Izrael se, prema riječima Davida Kretzmera, „suočava s upravljanjem napetosti između dviju koncepcija državnosti, kao demokratska država Izrael mora služiti potrebama svih svojih građana; kao država židovskog naroda njegova je zadaća slijediti partikularističke ciljeve“8.

Danas u Izraelu živi oko devet milijuna i tristo tisuća stanovnika. Od toga je broja 74 \% Židova, 21 \% Arapa i 5 \% ostalih. ${ }^{9}$ Glavni društveni rascjepi koji najdublje utječu na izraelsko društvo su oni između Židova i Arapa, zatim između Mizraha i Aškenaza, između religioznih i nereligioznih Židova te unutar rodnih odnosa. ${ }^{10}$ Tako su društveni rascjepi, uz povijesne okolnosti, uvelike utjecali na oblikovanje specifičnih političkih institucija koje su bile odgovor na podijeljenost društva, pa se od uspostave države Izrael karakter njezine demokracije nikada nije jasno iskristalizirao.

6 Usp. ALAN DOWTY, „Is Israel Democratic? Substance and Semantics in the "Ethnic Democracy' Debate“, Israel Studies, Bloomington, Indiana University Press, god. IV. (1999.)br. 2., str. 1.

Usp. isto, str. 6.

$8 \quad$ Isto, str. str. 7.

$9 \quad$ Israel Central Bureau of Statistics, <https://www.cbs.gov.il/en>, (16. II. 2021.).

10 Vidi Yossi YonaH, „Israel As a Multicultural Democracy: Challenges and Obstacles“, Israel Affairs, Abingdon, Taylor \& Francis, god. XI. (2005.) br. 1., str. 95. - 116. 


\section{Etnička demokracija s nedemokratskim obilježjima}

Etnička demokracija primjer je alternativnoga oblika demokratske države koji se institucionalno poistovjećuje s jednom etničkom skupinom uz istovremeno priznavanje građanskih prava svih pojedinaca. Termin je nastao upravo prilikom opisa stanja političke stvarnosti u Izraelu. Etnička je demokracija prijeporan pojam. Neki je politolozi uopće ne svrstavaju u demokratske modele političkoga uređenja, opisuju je kao etnokraciju koja se svodi na tiraniju etničke većine nad manjinama. Drugi je svesrdno prihvaćaju kao legitiman model demokratskoga političkog uređenja. ${ }^{11}$

Prema kriterijima koje je postavio Sammy Smooha, etnička je demokracija demokratski politički sustav koji kombinira proširenje građanskih i političkih prava za sve građane sa stalnim boravkom, koji žele postati državljani, uz istovremeno davanje povlaštena statusa većinskoj skupini. ${ }^{12}$ Države u kojima ima elemenata etničke demokracije, osim reprezentativnoga primjera izraelskoga modela, jesu Slovačka, Estonija, Sjeverna Irska u razdoblju od 1921. do 1972. godine, Poljska od 1918. do 1935. godine, Malezija od početka 1970-ih, dok je Njemačka na granici. ${ }^{13}$

Neka su od obilježja etničke demokracije: dominacija jedne etničke skupine, kontradikcija između građanskih i političkih prava za sve i strukturalna podređenost manjina, usmjerenost političke elite na izgradnju demokracije, otpor manjina bez državne represije, identifikacija države s dominantnom etničkom skupinom, a ne s građanima, mogućnost izgradnje homogene etničke nacije i sl.

Etnička demokracija temelji se na ugrađenoj kontradikciji između proširenja prava i sloboda za sve i institucionaliziranja etničke

${ }^{11}$ To je posebno vidljivo među židovskim i palestinskim politolozima iz Izraela. Za prve je etnička demokracija legitiman oblik demokratskoga političkog uređenja, a za druge nedemokratska etnokracija. Usp. M. KASAPOvć, $n$. dj., str. 259.

12 Usp. S. SмоOна, The Model ..., str. 5.

${ }_{13}$ „The ethnic democracy model is non-western in essence, but it is to a certain degree also relevant to Germany. In Germany a clearcut distinction is made between a German core ethnic nation and non-core groups. Germany lacks an immigration law despite the existence of millions of immigrants and practices a policy of restricting citizenship to ethnic Germans (it absorbed about 15 million of them since 1945 as ,returnees', not immigrants) as much as possible." Isto, str. 86. 
dominacije. To je demokracija koja u sebi sadrži nedemokratski element upravo preko mogućnosti institucionalizacije dominantne etničke skupine. Pri tome je glavno načelo pravilo koje omogućava postojanje kontradikcije između građanskih i političkih prava te postojanje sustavne podređenosti manjina većini. Demokratsko načelo pri tome osigurava jednakost državljana i svih članova društva, dok etničko omogućava etničku nejednakost u smislu privilegirana statusa i dominacije povlaštene etničke skupine. ${ }^{14}$ Demokratski element zastupljen je ako odgovara dominantnoj etničkoj skupini i njezinim interesima u smislu predstavljanja legitimnosti, u unutarnjim i međunarodnim političkim odnosima.

Međutim, da bi se određeni politički sustav mogao obilježiti kao etnička demokracija, u njemu mora biti omogućeno funkcioniranje pravne države te mora postojati jamstvo minimalnih manjinskih prava. ${ }^{15}$ Za takav oblik demokracije može se reći da je opisan i analitički, a ne normativan model, iako može uživati međunarodnu legitimnost, kao u slučaju Izraela. Specifičan model uspostavljen u Izraelu uživa međunarodni legitimitet te se, stoga, smatra prihvatljivim oblikom demokracije modelirane za podijeljena društva. Država Izrael, osnovana 1948. godine, nema pisan ustav zbog izrazito suprotstavljenih stavova pojedinih političkih subjekata oko njegova sadržaja te ga zamjenjuje Deklaracija o neovisnosti, zajedno s jedanaest temeljnih zakona. Deklaracija i temeljni zakoni uređuju djelovanje političkih i društvenih institucija. ${ }^{16}$ Deklaracija definira Izrael kao židovsku i demokratsku državu te državu koja daje domovinu židovskomu narodu i svim Židovima iz dijaspore jamči mogućnost povratka u Izrael. ${ }^{17}$

Izrael je etnička demokracija sa židovskom većinom, koja vuče korijene iz brojnih država Europe i svijeta, te s arapsko-palestinskom

Usp. isto, str. 21.

15 Usp. Sammy Smоoнa, „Types of Democracy and Models of Conflict Managment in Ethnically Divided Societies", Nations and Nationalism, Special Issue, Hoboken, Wiley-Blackwell, god. VIII. (2002.) br. 4., str. 424.

16 Usp. J. SinAI, $n$. dj., str. $181 .-184$.

${ }_{17}$ Usp. Declaration of Establishment of State of Israel, <http://www.mfa.gov.il/MFA/Peace + Process $/$ Guide + to + the + Peace + Process/Declaration + of + Establishment + of + State+of+Israel.htm>, (23. I. 2021.). 
manjinom. Unutarnja granica između ovih dvaju entiteta jasno je povučena. Međutim, spomenute linije sukoba unutar heterogenoga židovskog stanovništva, koje naglašavaju različito podrijetlo i klasnu pripadnost, pa čak i različitu razinu religioznosti, suprotstavljene stavove oko rješavanja izraelsko-palestinskoga sukoba, dodatno opterećuju načela demokracije. Sekularni krugovi traže jasniju podjelu između države i religije te se protive privilegiranu statusu ultraortodoksnih Židova. Javlja se i jaz između Židova koji su se uselili iz arapskih zemalja i onih iz Europe, jer prvi optužuju druge za dominaciju nad njima. Arapsko-palestinskoj manjini službeno su priznata građanska prava, no njihova im je realizacija rijetko dostupna, iako se Deklaracija o neovisnosti poziva na jednaka prava svih koji žive na državnome teritoriju, neovisno o religijskoj, rasnoj i drugoj pripadnosti. Protivno demokratskomu načelu zaštite manjina, etnička demokracija u Izraelu funkcionira na modelu tiranije većine uz isključenost manjine. Palestinska manjina isključena je iz države i političkoga sustava na više razina. Na ideološkoj su razini isključeni jer ih se svrstava kao građane drugoga reda, a na simboličkoj jer državni simboli ničim ne izražavaju da su njezini državljani i palestinski Arapi. Onemogućen im je pristup najvažnijim političkim i javnim institucijama te su uklonjeni iz procesa donošenja odluka o javnim politikama, posebice useljeničkoj, naseljeničkoj i zemljišnoj, koje zadiru u sami smisao opstanka palestinske zajednice..$^{18}$ Izrael se deklarirao kao židovska i demokratska država. To je domovina čitavoga židovskog naroda kojega više od 60 \% živi u dijaspori. ${ }^{19}$ Službena državna ideologija jest cionizam, a središnji je cilj očuvanje židovstva u demografskome, jezičnome, kulturnome, institucionalnome, identitetskome i simbolskome smislu diljem svijeta. Cionizam shvaća povijesni razvoj židovstva kao etničkoga naroda kojemu su nacionalnost i religija isprepleteni.

Središnju ulogu u Izraelu igra upravo religija. ${ }^{20}$ Ortodoksnomu židovstvu povjereno je očuvanje etnonacionalnih interesa. Onemogućava

18 Usp. M. KASAPOVIĆ, $n$. dj., str. 264

19 Vidi: Bernard Avishai, The tragedy of Zionism: How its revolutionary past haunts Israeli democracy, Helios Press, New York, 2002.

2o Iako je religija neupitna kada je u pitanju Izrael, sekularnost je ključna za nastanak te države. „Ako bismo morali odabrati jedan fenomen koji je bio ključan za nastanak moderne 
se stvaranje multireligijskoga i multietničkoga društva. Ne postoje građansko sklapanje braka i razvod te se legitimira i provodi endogamija. Time je pripadnost židovstvu odvojena od državljanstva. Drugo je uporište židovske moći zakon koji im omogućava slobodno useljavanje i naseljavanje te dobivanje automatskoga državljanstva, dok se, s druge strane, poriče pravo povratka izbjeglih palestinskih Arapa. Hebrejski je jezik službeni i dominantni, dok je arapski, također, službeni, ali ne i dominantni.

Arapi u Izraelu uživaju ljudska, socijalna, građanska i politička prava. Postoje arapski mediji i školski sustav, kulturne i vjerske ustanove. Sve te institucionalne aranžmane djelomično financira država. Arapi žive u odvojenim zajednicama i nisu izloženi pritisku asimilacije. Međutim, njihova su prava nepotpuna. Diskriminacija je široko rasprostranjena, ali im je ipak omogućeno sudjelovanje na izborima za zakonodavno tijelo Kneset. Od 120 članova Kneseta desetak ih Arapi redovito izabiru za svoje predstavnike. Opsežno koriste mogućnost prosvjeda, organiziraju se u udruge civilnoga društva i sl. S druge strane, Arape se smatra potencijalno nelojalnima državi te su izloženi ogromnu sigurnosnom nadzoru. Izuzeti su od obveznoga vojnog roka te su isključeni i iz ostalih snaga sigurnosti. Arapska manjina definirana je kao visokorizična te država djeluje u trajnome stanju pripravnosti s neograničenim ovlastima otkrivanja i prevencije sigurnosnih prekršaja. ${ }^{21}$

Negrađanska obilježja Izraela transparentna su. Židovska nacionalnost temelji se na podrijetlu i religijskoj pripadnosti. Nacionalni identitet ima prednost nad državljanstvom. Izrael je etnička, a ne liberalna demokracija jer država ne priznaje samo pojedinca nego i etničku skupinu. To nije ni liberalna ni multikulturalna demokracija jer Židovi čine

izraelske države, u najuži bi izbor ušao - sekularizam. To može zazvučati čudno s obzirom na to da je religija jedna od glavnih odrednica u previranjima u suvremenome izraelskom društvu i prizma kroz koju mnogi Židovi i nežidovi promatraju projekt židovske državotvornosti u Svetoj zemlji.“ Boris Havel, „Sekularizam i nastanak Države Izrael“, Političke analize, Zagreb, Fakultet političkih znanosti, god. IV. (2013.) br. 15., str. 12.

${ }^{21}$ Jonathan Cook koristi metaforu „stakleni zid“ kojom opisuje način na koji Izrael isključuje Arape od svih utjecaja nastojeći istovremeno štititi vlastiti ugled demokratske države. Vidi: Jonathan Cook, Blood and Religion:The Unmasking of the Jewish and Democracy State, Pluto Press, London, 2006., str. 1. - 31.; 169. - 180. 
jezgru etničke nacije, a Arapi sporednu manjinu. ${ }^{22}$ Izrael je etnička, a ne konsocijacijska demokracija jer se država identificira sa židovskom većinom. Pojavu da politički sustav poštuje odijeljenost i samostalnost s razgranatošću mreža organizacija Lijphart naziva „federalizmom u unitarnoj državi“ te zato državu Izrael naziva „kvazifederacijom“ ${ }^{23}$ Čimbenici koji pridonose etničkoj demokraciji leže u činjenici da je Izrael plod cionističkoga projekta dizajnirana prema nacrtu židovskoga etničkog aranžmana pa ideja etničke države služi kao učinkovito sredstvo mobilizacije u židovsko-arapskim sukobima. Ipak, demokratski predznak države Izrael opravdava predanost cionizma demokratizaciji i njegova snažna orijentacija prema Zapadu kao i činjenica da je jedino demokracija najbolje upravljanje suparničkim židovskim skupinama.

Smooha tvrdi da Izrael i dalje može biti i židovska i demokratska država ako ispuni nekoliko uvjeta. Prvi je da Židovi ostanu većina, drugi je nastavak osjećaja prijetnje za opstanak židovske etničke nacije u Izraelu i inozemstvu. Treći je nastavak nespremnosti arapskoga svijeta i Palestinaca na intervenciju $u$ ime arapske manjine u Izraelu. Četvrti je nedostatak intervencije međunarodne zajednice da zaštiti arapsku manjinu te da utječe na promjenu strukture političkoga sustava Izraela. ${ }^{24}$ Etnička konfiguracija izraelske demokracije toliko je duboko ukorijenjena da prelazak u građanski tip demokracije nije vjerojatan u doglednoj budućnosti. Ona je temelj na kojemu su kasnije ugrađivani ostali oblici demokracije u povijesti izraelske države. ${ }^{25}$ Židovi čvrsto vjeruju da je izraelska demokracija liberalna demokracija i činjenica je da je Izrael jedinstveno prihvaćen na Zapadu te da postoji međunarodni legitimitet za etničku demokraciju u Izraelu.

22 Usp. S. SмоOHa, The Model ..., str. 55.

23 Arend Lijphart, Democracy in Plural Societies: A Comparative Exploration, Yale University Press, New Haven, 1977., str. 130.

${ }_{24}$ Usp. S. SмоOHa, The Model..., str. 60.

25 Usp. M. KaSAPOVIĆ, $n$. dj., str. 259. 


\section{Etnokracija i politika judaizacije}

Etnokracija je oblik političkoga režima koji se često pojavljuje na svjetskoj političkoj karti, ali je društveni znanstvenici rijetko proučavaju i prepoznaju. To je režim koji olakšava širenje, kontrolu i etničku nadmoć dominantne etničke zajednice nad spornim teritorijem i državom. Definira se kao pravni, politički i moralni okvir koji određuje raspodjelu moći i resursa koji odražavaju identitet, ciljeve i praktične prioritete određene političke zajednice. Glavna je poluga režima država koja pruža institucionalne mehanizme, zakone i legitimirane oblike nasilja za provedbu jasno artikuliranih interesa. ${ }^{26} \mathrm{U}$ etnokraciji prava određuje etnonacionalno porijeklo, a ne opće građanstvo. Izvor je legitimiteta dominantna etnička zajednica koja prisvaja državni aparat i primjenjuje diskriminacijske politike prema drugim zajednicama. Društvom dominiraju tri pokretačke snage koje održavaju etnokraciju: doseljeničko društvo, etnički nacionalizam i etnička logika kapitala.

Na primjerima nepostojanja zaštite temeljnoga ljudskog prava i jednaka pristupa državnomu zemljištu svim građanima Oren Yiftachel daje početnu točku s koje nastoji dokazati kako bi izraelski režim trebalo klasificirati upravo kao etnokraciju. ${ }^{27}$ Budući da etnokracijama, unatoč demokratskim obilježjima, nedostaju demokratske institucionalne strukture, zbog tih nedostataka potkopava se percepcija da je Izrael i židovska i demokratska država. Slično Yiftachelu, i Na’eem Jeenah suprotstavlja se toj tvrdnji. Smatra da Izrael nije isključivo židovski, ali da

26 Oren Yiftachel, Ethnocracy: Land and Identity Politics in Israel/Palestine, University of Pennsylvania Press, Philadelphia, 2006., str. 11. - 12.

${ }_{27}$ Yiftachel se poziva na slučaj iz 1997. godine kada je Vrhovni sud odlučivao o žalbi Qa'adan protiv Katzira, koju je pokrenuo arapski građanin kojemu je onemogućeno davanje u zakup državnoga zemljišta u predgrađu mjesta Katzir - zato što nije Židov. Sud je odluku o predmetu maksimalno odgađao. Predsjednik Suda, sudac Aharon Barak, poznat kao zagovornik građanskih prava, istaknuo je kako je ovaj slučaj bio među najtežima u njegovoj pravnoj karijeri. U ožujku 20oo. presuđeno je u korist Qa'adana uz napomenu da su izraelske politike prema arapskoj manjini bile diskriminatorne i nezakonite. Ipak, sud nije obvezao Katzir da dopusti Qa'adanu zakup zemljišta, s obzirom na to da se nastojao distancirati kako ovaj slučaj ne bi postao presedan. Osim toga, lokalna židovska zajednica nastavila je postavljati administrativne i socijalne prepreke s namjerom da onemogući Qa'adanove planove da se naseli u Katziru. Usp. Oren Yiftachel, „'Ethnocracy': The Politics of Judaizing Israel/Palestine“, Constellations, Hoboken, John Wiley\&Sons, god. VI. (1999.) br. 3., str. 1. 
sigurno nije ni demokratska država. Obje su definicije u službi politike, radi stjecanja legitimiteta izraelske države i kao pokušaj maskiranja oblika etničkoga čišćenja. Istina je da je Izrael etnokratska država, možda bi točniji opis bio „židovska i etnokratska država“ “. ${ }^{28}$

Teorijsku podlogu etnokracije Yiftachel oslanja na tri glavna politička i povijesna razloga koji su oblikovali i politiku i teritorij Izraela. Prvi je razlog oblikovanje kolonijalnoga društva tako da se država uspostavlja prema percepciji unutar koje se institucionalizira dominacija jedne etničke skupine, uz jasno odvajanje od ostalih etničkih skupina. Drugi je mobiliziranje moći etnonacionalizma, političkoga pokreta koji se bori za postizanje i očuvanje etničke državnosti. To se postiže spajanjem dvaju načela političkoga poretka, postwestfalske podjele svijeta na suverene države i načela samoodređenja, uz pomoć kojih su i stvorene nacionalne države. Unatoč činjenici da se koncept nacionalne države poklapa s političkom realnošću, ovaj je model u Izraelu postao dominantan, kako zbog suverenosti, isto tako i zbog etničkoga samoodređenja koje je bilo glavni uzrok sukoba u pokušaju judaizacije zemlje, a sve u ime židovskoga samoodređenja. Treći je razlog etnička logika kapitala. Unutar te logike društvo naseljenika i etnonacionalizam zajedno stvaraju specifične odnose unutar kojih je tržište rada etnički podijeljeno uz istovremeno slabljenje ekonomske moći države uslijed globalizacije tržišta.

Yiftachel etnokraciju definira kao nestabilan nedemokratski režim koji pokušava proširiti i sačuvati nerazmjernu etničku kontrolu na spornome višeetničkom teritoriju pri čemu je dominantna zajednica dovoljno snažna da odredi samu prirodu državnoga aparata. Etnokratske režime klasificira prema ključnim obilježjima: raspodjela prava i obveza određuje se prema etničkoj pripadnosti, a ne državljanstvu; ne postoje državne i političke granice, niti postoji utvrđeni demos, uglavnom zbog uloge dijaspore, dok je izražena inferiornost etničkih manjina; državni aparat prisvaja dominantna etnička skupina uz istovremeno odvajanje od ostalih etničkih skupina; politička, stambena i ekonomska segregacija

${ }_{28}$ Na'eem Jeenah, „Pretending democracy, living ethnocracy“, Na'eem Jeenah (ur.) Pretending Democracy: Israel an Ethnocratic State, Afro-Middle East Centre, Johannesburg, 2012., str. 3 . 
i stratifikacija odvija se na etnonacionalnoj i etnoklasnoj razini; konstitutivna logika etnonacionalne segregacije raspršena je, što povećava proces političke etnizacije među podskupinama unutar svake etničke skupine; bitna, iako djelomična, građanska i politička prava proširena su na pripadnike manjinske etničke skupine. Uz to, Yiftachel naglašava da etnokratske režime obično podupiru kulturni i ideološki sklopovi koji legitimiraju i učvršćuju neujednačenu stvarnost. To postižu konstruiranjem povijesne naracije koja dominantnu skupinu proglašava kao zakonitoga vlasnika predmetnoga područja. Tvrdi da je selektivna otvorenost režima, koja omogućuje javni prosvjed, slobodu govora i periodične izbore, u velikoj mjeri iluzija: etnokratski je režim politički, kulturno i zemljopisno uređen tako da usisava, obuzdava ili ignorira izazov koji proizlazi iz njegovih periferija, zarobivši ih u njihovim nevoljama. ${ }^{29}$

Kada se 1948. godine Izrael proglasio „židovskom državom“, izričito se izjasnio na poticanje razvoja zemlje u korist svih njezinih stanovnika uz osiguranje potpune jednakosti socijalnih i političkih prava bez obzira na vjeru, rasu ili spol. ${ }^{30}$ I novoutemeljene političke institucije, većinom naslijeđene iz Jišuva, uspostavljene su kao demokratske: zastupničko tijelo s periodičnim izborima, neovisno sudstvo i slobodni mediji. S druge strane, s vremenom se pokazao židovski, a ne izraelski karakter države. To najviše potvrđuje Zakon o povratku i državljanstvu koji je svakoga Židova na svijetu učinio potencijalnim državljaninom, dok je to onemogućio mnogim Arapima rođenima u toj zemlji. I ostali zakoni potvrđuju židovski karakter države koji nije samo simboličan, već zadire u područja kao što su obrazovanje, komunikacija i vlasništvo nad zemljom. Godine 1985. revizijom Temeljnoga zakona o Knesetu propisano je da se nijedna stranka ne može natjecati na izborima ako odbije definiciju Izraela kao židovske države. Yiftachel tvrdi da je upravo kombinacija ovih dvaju zakona stvorila strukturu imunu na demokratske pokušaje da se promijeni cionistički karakter države. ${ }^{31}$ Pri tome ističe da glavna

29 Usp. Oren Yiftachel, "Ethnocracy, and its discontents: Minorities, protests, and the Israeli polity“, Critical Inquiry, Chicago, The University of Chicago, god XXVI. (20oo.) br. 4., str. 728.

3o Usp. Declaration of Establishment of State of Israel.

${ }_{31} \quad$ Usp. O. Yiftachel, 'Ethnocracy': The Politics..., str. 7. 
prepreka izraelskoj demokraciji ne mora nužno biti u činjenici da je Izrael proglašen židovskom državom, što uspoređuje s pravnim statusom Finske kao „luteranske“ ili Engleske kao „anglikanske“. Po njemu glavni problem leži u procesu judaizacije i dearabizacije, što se naročito ogleda kroz teritorijalnu rekonstrukciju zemlje usmjerenu na ekspanzionistički program koji je započeo bijegom Palestinaca tijekom rata 1948. i sprječavanjem njihova povratka uz istovremeno naseljavanje židovskih useljenika i izgradnju teritorijalne socijalizacije. Ta je vrsta socijalizacije bila izražena kroz školski program, književnost, političke govore, popularnu glazbu i ostale sfere javnoga diskursa. Percepcija zemlje kao samo židovske bila je zasnovana na diskursu "prisilna izgnanstva“ i naknadna "povratka“ uz reakciju na arapsko-židovski sukob, uzdižući nacionalnu sigurnost na neupitnu razinu. ${ }^{32}$

Kao izrazito važan element etnokracije smatra se i snažan utjecaj na političku moć Židova izvan Izraela u mjeri kakav nije zabilježen u demokratskim državama. Tome treba pridodati i sve veći utjecaj ortodoksnih židovskih skupina na donošenje političkih odluka, što neke autore navodi na zaključak da Izrael ide prema teokratskoj, a ne etnokratskoj vladavini ${ }^{33}$, dok nepostojanje državnih granica uz aktivno naseljavanje i uključivanje Židova iz cijeloga svijeta u unutarnju politiku bitno narušava teritorijalno i građansko značenje izraza ,izraelski“ te se istodobno ojačava neteritorijalni i etnoreligijski židovski kolektivni identitet. ${ }^{34}$ To potvrđuje i usidrenost vjerskoga karaktera države u različitim područjima. Ortodoksne političke stranke opravdavaju nametanje tih propisa sekularnoj javnosti tvrdnjom da se na taj način osigurava etnički karakter države za buduće generacije. Sprječavanje uključivanja nežidova omogućuje pretpostavke za židovsku etničku državu (etnokraciju). U tome kontekstu neizostavno je spomenuti da, osim sukoba između ortodoksnih i svjetovnih Židova, postoji i njihova dugogodišnja suradnja na projektu uspostave židovske etnokracije.

\footnotetext{
Usp. isto, str. 8.

Usp. isto, str. 13.
}

Usp. isto, str. 14. 
Godinama vodeći politički, akademski i diskursi šire zajednice odvojeno tretiraju arapsko-židovske i vjersko-sekularne probleme. Tako Yiftachel pod termin etnokracija segregacijskih naselja smješta sve političke, pravne i kulturne mehanizme kojima je svrha odvajanje Židova i ostalih, čime se pojačava proces „etnizacije“. ${ }^{35}$ Slični mehanizmi korišteni su i suptilnije unutar židovskoga korpusa između Aškenaza, Židova iz kršćanske Europe, i Mizrahima, orijentalnih Židova iz islamskih zemalja. Mizrahimi su bili prostorno marginalizirani u izraelskome projektu naseljavanja i smještani u izoliranim periferijama ili siromašnim četvrtima većih gradova. Postoji jasna veza koja povezuje dearabizaciju zemlje s marginalizacijom Mizrahima, koji su kulturno i prostorno bili svrstani između Arapa i Židova, između Izraela i njegovih neprijateljskih susjeda, između „zaostale“ istočne prošlosti i „napredne“ zapadne budućnosti. Ipak, dubina i opseg diskriminacije Palestinaca i Mizrahima bila je sasvim drugačija. Mizrahimi su bili uključeni u izgradnju države kao aktivni sudionici ugnjetavanja Palestinaca. ${ }^{36} \mathrm{U}$ zadnje vrijeme bilježi se sve veća razina asimilacije između Mizrahima i Aškenaza kao i sve veća formalna jednakost u društvenome statusu. Osim toga, unutaržidovska solidarnost pred zajedničkim neprijateljem ublažava i neutralizira sve unutarnje napetosti.

Ispitujući prirodu izraelskoga režima iz političko-prostorne perspektive, Yiftachel je pokazao da su tri glavne snage koje su oblikovale izraelsku politiku: uspostava društva doseljenika, mobilizacijska snaga etnonacionalizma i etnička logika kapitala, stvorile režim koji privilegira etnos u odnosu nad demos na spornome teritoriju koji je zaposjela dominantna skupina. Dokazuje kako se režim u Izraelu bitno oblikovao etnokratskim projektom judaizacije zemlje, što je dovelo do nepostojanja državnih granica, stalnoga uključivanja neteritorijalnih organizacija u sustav vlasti, ustrajne i nasilne vojne vlasti nad okupiranim palestinskim područjima oštećenja jednakoga državljanstva. ${ }^{37}$ Ključni čimbenik u razumijevanju izraelskoga režima leži u otkrivanju sofisticiranih

Usp. isto, str. 15.

Usp. isto, str. 16.

Isto, str. 17. 
institucionalnih okvira koji se predstavljaju kao demokratski, a u biti to nisu. Pravni i politički državni temelji stvorili su strukturu koja intenzivno osigurava prava za jednu etničku zajednicu u dvoetničkoj državi. No, Izrael ipak treba tretirati kao demokraciju. Razlozi za to leže u djelovanju mnogih važnih mehanizama koji podupiru demokratsku prirodu države. To su kompetitivna politika, izdašna građanska prava, neovisno sudstvo i medijske slobode. Nadalje, znanstvenici koriste niz definicija za izraelski režim, uključujući i liberalnu, ${ }^{38}$ ustavnu, konsocijacijsku i etničku demokraciju.

\section{Konsocijacija u unutaržidovskim podjelama}

Nizozemski teoretičar demokracije Arend Lijphart smatra se prvim koji je ponudio teorijsku formulaciju podjele moći ${ }^{39}$ premda on sam $\mathrm{u}$ svojoj studiji Thinking About Democracy: Power Sharing and Majority Rule in Theory and Practice ${ }^{40}$ ističe da je pojam "konsocijacijski“ prenio iz studije Davida E. Aptera The Political Kingdomin Uganda iz 1961. godine, a da se sam pojam može pratiti do djela Johannesa Althusiusa iz ranoga 17. stoljeća, koji je koristio latinski izraz consociatio. Lijphart upućuje na to da su se oba ova izvora našla u članku Consociational Democracy kao i u monografiji o „proporcionalnoj demokraciji“ Gerharda Lehmbrucha iz 1967. godine, koja je prethodila Lijphartovoj nizozemskoj studiji slučaja. Sam Lijphart priznaje kako je kasnije otkrio i druge presedane: posebice monografiju Sir Arthura Lewisa Politika u zapadnoj Africi iz 1965. godine, za koju tvrdi da je prvo moderno znanstveno izlaganje konsocijacijske teorije, te spise austromarksista Otta Bauera i Karla Rennera u ranim godinama 20. stoljeća..$^{41}$ Bez obzira na činjenicu da su mu prethodila slična istraživanja drugih vrsnih imena, Lijpharta

${ }_{38}$ Vidi Gabriel Sheffer, „Has Israel Really Been a Garrison Democracy? Sources of Change in Israel's Democracy“, Israel Affairs, Abingdon, Taylor \& Francis, god. III. (1996.) br. 1., str. 13. -38 .

39 Usp. Arend Lijphart, „Consociational Democracy“, World Politics, Cambridge University Press, Cambridge, god. XXI. (1969.) br. 2., str. 207. - 225.

40 Arend Lijphart, Thinking About Democracy: Power Sharing and Majority Rule in Theory and Practice, Routledge, Abingdon, 2008.

${ }_{41}$ Usp. isto, str. 3. -4 . 
se ipak smatra predvodnikom i najistaknutijim teoretičarem konsocijalizma. Glavne postavke Lijphartova konsocijalizma počivaju na tezi da je za podijeljena društva potreban poseban oblik demokracije, a taj je oblik konsocijacijska demokracija. Lijphart je određene demokracije u određenome vremenskom razdoblju identificirao kao neliberalne, konsocijacijske demokracije (Belgija, Švicarska, Austrija, Nizozemska) ili kao polukonsocijacijske, nekonsocijacijske demokracije s elementima konsocijacije (Kanada, Izrael, Sjeverna Irska). ${ }^{42}$ Posebnost je konsocijacijske demokracije ta da se u njoj nastoji postići visok stupanj političke stabilnosti u podijeljenome društvu, suprotno očekivanjima koja se temelje na njihovoj snažnoj društvenoj fragmentiranosti. Lijphart je izdvojio četiri glavne institucionalne karakteristike konsocijacijskih demokracija: načelo velike koalicije, uzajamno pravo veta za segmente, načelo proporcionalnosti u javnim službama i raspodjeli resursa te načelo segmentalne autonomije. ${ }^{43}$ Lijphart omekšava svoj izvorni teorijski okvir ističući „činjenicu da sve četiri konsocijacijske značajke mogu poprimiti sasvim različite oblike, ali, istodobno, da ti različiti oblici ne djeluju jednako dobro i da ih nije jednako preporučiti višeetničkim i višereligijskim društvima koja pokušavaju uspostaviti konsocijacijske institucije" ${ }^{44}$.

Iako je najvažniji društveni rascjep u Izraelu onaj između Židova i Arapa, unutar židovske zajednice dominira snažna podjela između Židova zapadnoga podrijetla i Židova istočnoga podrijetla. Međutim, glavni rascjepi na temelju dijeljenja među Židovima koje čine Izrael pluralnim društvom religijske su i ideologijske naravi. Stoga Lijphart uočava da Izrael ima dovoljno konsocijacijskih značajki te ga naziva polukonsocijacijskim režimom. ${ }^{45}$ Postoje tri segmenta: socijalisti, sekularizirani nesocijalisti i religiozni Židovi. Svaki je od njih sveobuhvatan i samodovoljan pa Židovi te subkulture nazivaju mahane ili kamp. Najuočljiviji konsocijacijski element izraelske demokracije stoga je autonomija

\footnotetext{
42 Usp. A. Lijphart, Democracy in Plural..., str. 2. - 134.

43 Usp. isto, str. 25. - 42.

$44 \quad$ A. LiJPHART, Thinking About... str. 4.

45 Usp. A. Lijphart, Democracy in Plural..., str. 129.
} 
segmenata jer sustav vlasti poštuje odijeljene i samostalne segmente, kampove, sa svojim raširenim mrežama organizacija. Druga dva jako izražena konsocijacijska načela jesu proporcionalnost i veto. S obzirom na čist razmjerni izborni sustav i činjenicu da cijela zemlja predstavlja jedinstveni izborni okrug sa zatvorenim blokiranim listama, čak i vrlo male stranke mogu ući u Kneset. Takozvana metoda stranačkoga ključa pri dodjeli položaja i financijskih sredstava osigurava dosljednu primjenu načela proporcionalnosti. Važan instrument u rukama religijskih skupina jest mogućnost korištenja veta, posebice kada se radi o spornim pitanjima uloge vjere u državi. ${ }^{46}$ Lijphart primjećuje da se, nasuprot snažnoj konsocijacijskoj prirodi izraelske demokracije, posebice kada se radi o tri važna, ali sekundarna načela: autonomija, veto i proporcionalnost, Izrael jedva približava primarnomu konsocijacijskom načelu, velikoj koaliciji. Ipak, izraelska demokracija djeluje upravo kroz koalicijske vlade. ${ }^{47} \mathrm{Da}$ bi se održale koalicije, najvažniji je politički proces pregovaranje uz prilagodbe. Politike održavanja koalicija na okupu transformiraju osmišljene programe političkih stranaka, reinterpretacijom u koalicijske političke programe, usprkos političkoj raznolikosti njihovih sastavnica. Održavanje koalicija na okupu nije samo međustranačko pregovaranje, ono vodi ka stabilnosti upravljanja i u podijeljenome društvu ka održavanju na okupu..$^{48}$ Izrael ispunjava gotovo sve povoljne uvjete $^{49}$ koji vode konsocijaciji: izrazito povoljan čimbenik postojanja snažnih prevladavajućih privrženosti koje imaju suprotan učinak od podjela na različite segmente, mala površina koja stvara unutarnje jedinstvo te, konačno, snažna tradicija u suradnji elita koja se razvila unutar cionističkoga pokreta i u Jišuvu..$^{\circ}$

Stupanj korištenja akomodacijskih praksi u Izraelu povezan je s obilježjima političkih elita kao i samom prirodom društvenih rascjepa.

\footnotetext{
46 Usp. isto, str. 131.

$47 \quad$ Vidi M. Kasapović, $n$. dj., str. 220. - 225.

48 Vidi Efraim Torgovnik, „Policy Change in Governmment Coalitions and Party Politics“, Dani Korn (ur.) Public Policy in Israel: Perspectives and Practices, Lexington Books, Lanham - Boulder - New York - Oxford, 2002., str. 79. - 93.

49 Usp. A. Lijphart, Democracy in Plural..., str. 53. - 103.

so Usp. isto, str. 134.
} 
Zbog toga politička institucionalizacija rascjepa može ojačati potrebu za suradnjom između predstavnika različitih skupina kako bi se očuvala politička stabilnost. Upravo je institucionalizacija društvenih podjela važna za uspješnu primjenu akomodacijskih politika. ${ }^{11}$ Posljednjih je godina konsocijacijski sustav odlučivanja u Izraelu bio pod sve većim pritiskom, čak i u sferi religije i države. To pokazuje široku kritiku sustava uz prijedloge koji su išli ka uvođenju temeljnih promjena u društvu. ${ }^{52}$ Rastući pritisci na konsocijacijski sustav u vjerskome području odnosili su se na useljavanja Židova iz bivšega Sovjetskog Saveza, od kojih su religiozni Židovi činili samo neznatnu manjinu. Još jedan čimbenik koji je dodatno opteretio konsocijacijski sustav odlučivanja bio je rastući prodor u izraelsku kulturu i društvo liberalnih zapadnih vrijednosti koje promoviraju zaštitu individualnih prava i sloboda.

Suvremene političke i akademske rasprave u Izraelu rezultirale su dvama glavnim konsocijacijskim pravcima. Prvi sugerira da je, iako bi Izrael trebao zadržati svoj židovski karakter, potrebno priznati pravo Palestinaca na kulturnu autonomiju, dok drugi sugerira da je Izrael zapravo pretvoren $u$ dvonacionalnu državu, ${ }^{53}$ iako perspektiva dviju odvojenih država postaje teško ostvariva. Sve je teže osigurati ili židovsku ili palestinsku homogenost zbog postojanja bitne palestinske manjine unutar izraelskih granica iz 1948. i zbog porasta židovskih naselja na okupiranim područjima, posebno Zapadnoj obali. Židovsko i palestinsko stanovništvo rašireno je na ograničenome području što traži blisku suradnju, dok zahtjevi za pretvaranje Izraela u dvonacionalnu državu nailaze na žestoke prigovore većine Židova koji vjeruju da su ti zahtjevi nespojivi s njihovim moralno utemeljenim pravom na samoodređenje. Posljedica je toga dodatna konsolidacija Palestinaca i njihovo otuđenje od države Izrael. ${ }^{54}$ Tome treba dodati činjenicu da je „iz temeljnog kompromisa o političkom sustavu Izraela otpočetka bio isključen arapski

${ }^{51}$ Usp. Elizier Don-Yeniya, „Public Policy and Management of Major Political Cleavages“, DAni Korn (ur.) Public Policy in Israel..., str. 11.

${ }^{52}$ Prijedlozi su kulminirali izjavama bivšega premijera Baraka o planiranoj „građanskoj revoluciji“. Isto, str. 24.

$53 \quad$ Usp. Y. YonaH, $n$. dj., str. 102.

${ }_{54}$ Usp. isto, str. 103. 
segment društva, pa se stoga ne može govoriti o konsocijacijskoj demokraciji u punom značenju tog pojma. (...) A isključenost jednog vjerski, etnički i kulturno važnog segmenta iz kompromisa i konsenzusa o temeljima političke zajednice, kao i iz institucija konsocijacijske demokra-

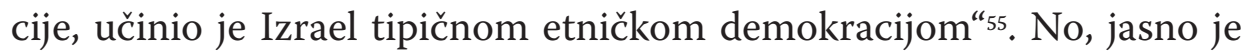
da su etnički, ali i drugi, rascjepi glavna prepreka demokraciji. Izrael se, stoga, suočava s političkom stvarnošću podijeljena društva balansirajući između demokratskih i nedemokratskih oblika upravljanja te, unatoč kritikama, uspijeva održati stabilnost sustava vlasti i globalno priznatu demokratsku legitimnost.

\section{Zaključak}

Velik je broj političkih znanstvenika koji su pokušali osporiti ocjenu da je Izrael puna demokracija. Nije previše izazovno dokazati kako Izrael ne ispunjava visoke demokratske standarde poput, prije svega, pune ravnopravnosti svih građana, dok ga je prilično lagano ocijeniti kao manjkavu demokraciju ili čak kao nedemokraciju. Ipak, međunarodno se Izrael svrstava u demokratske sustave vlasti. Osebujnu izraelsku demokraciju znanstveno se pretežito klasificira kao etničku demokraciju, etnokraciju ili konsocijacijsku demokraciju. Glavni razlozi za kritiku i osporavanje demokratske prirode države Izrael nedemokratski su elementi. Etničku se demokraciju kritizira zbog nelegitimnosti, nestabilnosti i neučinkovitosti, zbog tinjajućih sukoba. Tvrdi se da se zapravo radi o etnokraciji u kojoj dominantna etnička skupina kontrolira sve poluge moći, političke, ekonomske i društvene, dok su druge etničke skupine uključene na krajnje nerazmjeran i nepovoljan način. Ipak, glavni je aspekt izraelske demokracije upravljanje različitostima, pa je izraelska politika u osnovi konsocijacijska, ali samo unutar židovske zajednice i ne u suočavanju sa židovsko-arapskom podjelom. Kako god je zvali, demokracija je u Izraelu održiva i stabilna, uspijeva ublažiti unutaržidovske društvene rascjepe, dok glavni i najdublji rascjep, onaj između Židova i

$55 \quad$ M. Kasapović, $n$. dj., str. 267. 
Arapa, jedini koji zasjenjuje sve ostale, čvrsto ostaje odražavati dinamiku društva i politike u Izraelu.

\section{Literatura}

- Avishai, Bernard, The tragedy of Zionism: How its revolutionary past haunts Israeli democracy, Helios Press, New York, 2002.

- Chapin Metz, Helen (ur.), Israel A Country Study, Library ofCongress, Washington, 1990.

- Cook, Jonathan, Blood and Religion: The Unmasking of the Jewish and Democracy State, Pluto Press, London, 2006.

- Declaration of Establishment of State of Israel, <http://www. mfa.gov.il/MFA/Peace+Process/Guide+to+the+Peace+Process/ Declaration + of + Establishment + of + State + of + Israel.htm $>$, (23. I. 2021.).

- Don-Yehiya, Elizier, „Public Policy and Management of Major Political Cleavages“, DAni Korn (ur.) Public Policy in Israel: Perspectives and Practices, Lexington Books, Lanham - Boulder New York - Oxford, 2002., str. 9. - 30.

- Dowty, Alan, „Is Israel Democratic? Substance and Semantics in the 'Ethnic Democracy' Debate", Israel Studies, Bloomington, Indiana University Press, god. IV. (1999.) br. 2., str. 1. - 15.

- Havel, Boris, „Sekularizam i nastanak Države Izrael“, Političke analize, Zagreb, Fakultet političkih znanosti, god. IV. (2013.) br. 15., str. 12. -18 .

- Hazan, Reuven Y. i dr., „Introduction to Israeli Politics and Society", HazAn, Reuven Y. i dr., (ur.) The Oxford Handbook of Israeli Politics and Society, Oxford Univeristy Press, New York, 2021., str. 1. -15 .

- Israel Central Bureau of Statistics, <https://www.cbs.gov.il/en>, (16. II. 2021.). 
- Jeenah, Na'eem, „Pretending democracy, living ethnocracy“, JeeNAH, Na'eem (ur.) Pretending Democracy: Israel an Ethnocratic State, Afro-Middle East Centre, Johannesburg, 2012., str. 3. - 23.

- Kasapović, Mirjana, Politički sustav i politika Izraela, Politička kultura, Zagreb, 2010.

- Lijphart, Arend, Democracy in Plural Societies: A Comparative Exploration, Yale University Press, New Haven, 1977.

- Lijphart, Arend, „Consociational Democracy”, World Politics, Cambridge University Press, Cambridge, god. XXI. (1969.) br. 2., str. 207. - 225 .

- Lijphart, Arend, Thinking About Democracy: Power Sharing and Majority Rule in Theory and Practice, Routledge, Abingdon, 2008.

- Sheffer, Gabriel, „Has Israel Really Been a Garrison Democracy? Sources of Change in Israel's Democracy“, Israel Affairs, Abingdon, Taylor \& Francis, god. III. (1996.) br. 1., str. 13. - 38.

- Sinai, Joshua, „Government and Politics“, Chapin Metz, Helen (ur.), Israel A Country Study, Library of Congress, Washington, 1990., str. 177. -248.

- Smoona, Sammy, „Types of Democracy and Models of Conflict Management in Ethnically Divided Societies", Nations and Nationalism, Special Issue, Wiley-Blackwell, Hoboken, god. VIII. (2002.) br. 4., str. 423. -431.

- Smoona, Sammy, The Model of EthnicDemocracy, European Centre for Minority Issues, Flensburg, 2001.

- Torgovnik, Efraim, „Policy Change in Governmment Coalitions and Party Politics“, Korn, Dani (ur.) Public Policy in Israel: Perspectives and Practices, Lexington Books, Lanham - Boulder - New York - Oxford, 2002., str. 79. - 93.

- Yiftachel, Oren, „Ethnocracy': The Politics of Judaizing Israel/ Palestine“, Constellations, Hoboken, John Wiley\&Sons, god. VI. (1999.) br. 3., str. 364. - 390. 
- Yiftachel, Oren, Ethnocracy: Land and Identity Politics in Israel/Palestine, University of Pennsylvania Press, Philadelphia, 2006.

- Yiftachel, Oren, „Ethnocracy, and its discontents: Minorities, protests, and the Israeli polity", Critical Inquiry, Chicago, The University of Chicago, god XXVI. (200o.) br. 4., str. 725. - 756.

- YonaH, Yossi, „Israel As a Multicultural Democracy: Challenges and Obstacles", Israel Affairs, Abingdon, Taylor \&Francis, god. XI. (2005.) br. 1., str. 95 - 116. 
Review article

Received on December 2, 2020 Accepted on March 13, 2021

GORDANA ILIČIĆ

University of Mostar, Faculty of Humanities and Social Sciences

\section{ALTERNATIVE FORMS OF A DEMOCRATIC STATE: THE CASE OF ISRAEL}

\section{Abstract}

Although democracy in Israel is sustainable and stable, it does not match any of the western types of democracy. Israel is a typical divided society whose political system and social structure do not often make a great deal of sense for the rest of the world. This paper represents a brief analysis, based on theoretical frameworks and typological placement of democracy which is closely connected to social rifts of the Israeli society. The paper investigates if democracy in Israel was being developed in order to facilitates the social divisions management and if it alleviated or strengthened social rifts.

Keywords: Israel; ethnic democracy; ethnocracy; consociation; divided society 